\title{
TATA KELOLA MODEL IT GOVERNANCE PADA LAYANAN AKADEMIK MENGGUNAKAN FRAMEWORK COBIT 4.1 PADA DOMAIN (DELIVERY AND SUPPORT) DAN (MONITORING AND EVALUATION)
}

\author{
Hermawaty \\ STMIK "AMIKBANDUNG" \\ Jl. Jakarta No.28, Kebonwaru, Batununggal, Kota Bandung \\ e-mail:emma@stmik-amikbandung.ac.id
}

\begin{abstract}
Abstrak
Peranan sistem informasi akademik di Sekolah Tinggi Manajemen Informatika dan Komputer "AMIK BANDUNG" (STMIK "AMIKBANDUNG") saat ini sudah diterapkan, namun belum dikelola dengan menggunakan pendekatan dan metoda terstruktur, sehingga ada kesulitan dalam mengukur peranan teknologi informasi untuk mencapaian tujuan institusi secara efektif dan efisien. Metodelogi penelitian yang digunakan dalam penelitian ini adalah pengumpulan data berupa observasi, wawancara serta penyebaran kuesioner. IT Governance (Information Technology Governance) adalah faktor penting bagi suatu organisasi di institusi dalam memanfaatkan teknologi informasi, yang akan memberikan jaminan bahwa pemanfaatan teknologi informasi selaras dengan tujuan organisasi. Dalam penelitian ini menggunakan framework COBIT 4.1. berdasarkan pertimbangan, bahwa COBIT 4.1. dibuat dengan menggunakan standar IT sebagai referensi sehingga keselarasan pengembangan IT dengan tujuan institusi relatif lebih terjamin. Alat yang digunakan untuk memetakan posisi proses sistem informasi adalah dengan menggunakan kuesioner. Kuesioner dibuat dengan menggunakan teknik pengukuran skala prioritas. Dari hasil penelitian ini diperoleh bahwa peranan IT terhadap institusi dalam skala model maturity ada pada skala 4 (managed), artinya bahwa institusi dapat mengukur dan memonitor prosedur yang ada sehingga mudah ditanggulangi jika terjadi penyimpangan. Kesimpulan dari penelitian ini bahwa hasil pemetaan proses TI di peroleh gambaran, bahwa posisi institusi untuk tiap proses rata - rata berada ditingkat (level) maturity ke-empat yaitu diatur, artinya dalam pelaksanaan TI di institusi selama ini sudah mengikuti pola yang teratur, namun harus tetap mengawasi dan mengevaluasi dari setiap proses yang ada.
\end{abstract}

Kata kunci : Maturity, Cobit, IT Governance, managed

\begin{abstract}
The role of academic information system in the High School of Information and Computer Management "AMIK BANDUNG" (STMIK "AMIKBANDUNG") is now implemented, but has not been managed using structured approaches and methods, so there is difficulty in measuring the role of information technology to achieve institutional goals Effective and efficient. The research methodology used in this research is data collection in the form of observation, interview and questionnaire distribution. IT Governance (Information Technology Governance) is an important factor for an organization in the institution in utilizing information technology, which will provide assurance that the use of information technology aligned with organizational goals. In this study using COBIT framework 4.1. Based on consideration, that COBIT 4.1. Made using IT standards as a reference so that the alignment of IT development with the goal of the institution is relatively more secure.
\end{abstract}


The tool used to map the position of the information system process is to use a questionnaire. Questionnaires were made using priority scale measurement techniques. From the results of this study obtained that the role of IT to institutions in the scale of model maturity is on scale 4 (managed), meaning that institutions can measure and monitor the existing procedures so easily addressed if there is deviation. The conclusion of this research is that the result of IT process mapping is obtained from the description that the institutional position for each process is on average at the fourth level of maturity that is regulated, meaning that IT implementation in the institution has been following a regular pattern, but shoul be supervised and evaluate from each process.

Kata kunci : Maturity, Cobit, IT Governance, managed

\section{PENDAHULUAN}

\subsection{Latar belakang Masalah}

Perguruan Tinggi dapat bertahan (survive) dan bisa mencapai kesuksesan, apabila perguruan tinggi tersebut harus bisa mengatur informasinya secara efektif dan efisien. IT Governance, merupakan teknologi informasi yang mengatur informasi secara efektif dan efisien. Pengaturan teknologi informasi yang baik, maka institusi akan meraih keuntungan dari nilai tambah informasi dengan memanfaatkan peluang, modal, keuntungan dan mendapatkan keunggulan yang kompetitif. Selain mengatur informasi, perguruan tinggi atau institusi juga harus bisa memberikan pelayanan yang baik didalam kegiatan sivitas akademik. Pelayanan akademik tidak hanya terhadap mahasiswa tetapi juga pelayanan untuk seluruh pihak terkait dengan proses akademik yang ada seperti dosen, alumni, dan juga orang tua, bahkan calon mahasiswa.

Tata Kelola IT Governance dalam penelitian ini menggunakan framework COBIT 4.1 (Control Objectives For Information And Related Technology), dimana tujuan utama COBIT adalah memberikan kebijaksanaan yang jelas dan latihan yang bagus bagi IT Governance untuk institusi serta membantu memahami dan mengatur resiko-resiko yang berhubungan dengan IT.

Penelitian ini dilaksanakan di BAAK STMIK"AMIKBANDUNG" mengambil domain Delivery Support (DS) dan Monitor Evaluate (ME), adapun pengolahan datanya menggunakan metoda AHP (Analytical Hierarchy Process). AHP merupakan suatu model pendukung keputusan yang dikembangkan oleh Thomas L. Saaty. Model pendukung keputusan ini akan menguraikan masalah multi faktor atau multi kriteria yang kompleks menjadi suatu hirarki. Dalam hal ini hirarki didefinisikan sebagai suatu representasi dari sebuah permasalahan yang kompleks dalam suatu struktur multi level dimana level pertama adalah tujuan, yang diikuti level faktor, kriteria, sub kriteria, dan seterusnya ke bawah hingga level terakhir dari alternatif. Dengan hirarki, suatu masalah yang kompleks dapat diuraikan ke dalam kelompok-kelompoknya yang kemudian diatur menjadi suatu bentuk hirarki sehingga permasalahan akan tampak lebih terstruktur dan sistematis. Dalam hal ini metoda AHP dipergunakan untuk menghitung skala prioritas pada domain Delivery Support (DS) dan Monitoring and Evaluation (ME) yang akan menghasilkan control process dengan tingkat vektor eigen yang tertinggi. Kemudian akan diperiksa konsistensi hirarki, dimana yang diukur adalah rasio konsistensi dengan melihat index konsistensi. Rasio konsistensi diharapkan kurang dari atau sama dengan 10\%, sehingga jawaban dari setiap responden bisa dipertangunggjawabkan. 
Permasalahan yang ada di STMIK "AMIKBANDUNG" adalah belum adanya evaluasi terhadap pelayanan sistem informasi akademik, dengan menggunakan pendekatan dan metode yang terstruktur. Berdasarkan masalah tersebut di atas, penulis mencoba menggunakan framework Cobit, sehingga mampu merekomendasikan dari hasil pemetaan level maturity.

\subsection{Identifikasi Masalah}

Berdasarkan latar belakang di atas maka dapat dibuat identifikasi masalah yaitu :

1. Belum adanya evaluasi dan arahan dalam proses IT Governance yang mendukung ketersediaan layanan bagi sistem informasi akademik.

2. Pelayanan sistem informasi belum dikelola dengan menggunakan pendekatan dan metoda terstruktur, sehingga sulit mengukur seberapa besar peranan teknologi informasi dalam mendukung pencapaian tujuan perusahaan secara efektif dan efisien.

\subsection{Rumusan Masalah}

Adapun rumusan masalah dalam penelitian ini adalah sebagai berikut :

1. Bagaimana pelaksanaan IT Governance pada sistem informasi akademik di STMIK "AMIKBANDUNG" yang belum selaras dengan kerangka kerja COBIT khususnya domain Deliver and Support (DS) dan Monitor and Evaluate (ME).

2. Bagaimana pemetaan pada tingkat model maturity sistem informasi di STMIK "AMIKBANDUNG".

3. Bagaimana mencapai tujuan pengendalian proses institusi yang berdasarkan Critical Success Factors (CSF).

\subsection{Tujuan Penelitian}

Tujuan dari penelitian ini sebagai berikut :

1. Menerapkan pedoman manajemen (management guidelines) yang ada pada COBIT di STMIK “AMIKBANDUNG", yang terdiri dari model maturity, dan Critical Success Factors (CSF) untuk domain Delivery Support (DS) dan Monitoring Evaluation (ME).

2. Mengkaji posisi setiap control process dengan cara memetakannya menggunakan alat model maturity.

3. Mengimplementasikan rancangan model IT Governance berdasarkan Critical Success Factors (CSF).

\subsection{Metode Penelitian}

Metode penelitian yang digunakan dalam penelitian ini adalah :

1. Pengumpulan Data

a. Studi lapangan terhadap proses bisnis dan sistem yang sedang berjalan di Institusi

b. Observasi yaitu melakukan penelitian atau pengamatan langsung yang berhubungan dengan masalah yang dihadapi

c. Wawancara yaitu mengadakan tanya jawab dengan nara sumber atau pihak-pihak yang berhubungan dengan bagian pelayanan akademik yaitu di BAAK STMIK"AMIKBANDUNG"

d. Studi Literature

Yaitu melakukan pengumpulan data yang akan dilakukan dengan mempelajari berbagai sumber buku yang dijadikan sebagai gambaran dari penulisan penelitian ini.

2. Pengolahan Data 
Pada tahap ini, penulis melakukan pengolahan data dari kuesioner yang di isi oleh para responden. Pengolahan data menggunakan perhitungan skala prioritas dengan metoda Analytical Hierarchy Process (AHP), pada domain Plan and Organize (PO) dan Acquire and Implement $(A I)$. Dari hasil perhitungan tersebut didapatkan control process dengan nilai vektor eigen yang tertinggi. Kemudian diukur rasio konsistensi dengan melihat index konsistensi. Rasio konsistensi diharapkan kurang dari atau sama dengan 10\%, sehingga jawaban responden bisa dipertanggungjawabkan.

1. Analisa Data

Melakukan analisa data dan control objective yang diperoleh dari tingkat maturity.

Dari hasil perhitungan kuesioner yang terdiri dari banyaknya jumlah jawaban dan banyaknya jumlah pertanyaan maka akan diperoleh tingkat model maturity, sehingga bisa ditentukan posisi sistem informasi institusi pada saat ini.

a. Membuat rancangan model IT Governance untuk lingkungan Institusi

Rancangan IT Governance institusi diadopsi dari model COBIT. COBIT mempunyai tujuan pengendalian informasi dan teknologi terkait dan merupakan standar terbuka untuk pengendalian terhadap teknologi informasi yang dikembangkan dan dipromosikan oleh institut IT Governance.

b. Memberikan usulan Tata kelola IT (IT Governance).

Usulan untuk tata kelola IT (IT Governance) untuk domain Delivery Support (DS) dan Monitoring and Evaluation (ME) diberikan untuk meningkatkan efisiensi dan keefektivan pengelolaan teknologi informasi untuk meningkatkan kinerja layanan akademik.

\section{LANDASAN TEORI}

\subsection{Literature review penelitian teknologi informasi menggunakan metode COBIT}

1. Analisis Tata Kelola Teknologi Informasi ( It Governance ) pada Bidang Akademik dengan Cobit Frame Work Studi Kasus pada Universitas Stikubank Semarang, Agus Prasetyo Utomo dan Novita Mariana, volume 16 no 2, halaman 1 - 11.Tahun : 2011, ISSN : 08549524

Review : Informasi jurnal sangat detil mengenai permasalahan serta penjelasan solusi, adanya struktur kerangka yang lengkap sehingga data-data yang ditampilkan lebih jelas. Dalam penjelasan setiap bab menggunakan penyajian yang sangat panjang dan sering berulang-ulang, sehingga pembaca kesulitan untuk memahami isi dari jurnal.

2. Analisis Pengelolaan Teknologi Informasi Berbasis Framework COBIT 4.1 : Studi Kasus Pada PT Bhanda Ghara Reksa, Chintamia Bunga Sari Dewi, Jurnal Ilmiah Informatika Komputer Vol 19, No 3 (2014);

Review : Dalam pengumpulan data berupa penyebaran kuesioner, tidak membutuhkan waktu yang lama sehingga pengolahan datanya relatif lebih singkat, belum terdapat penggunaan KPI (Key Performance Indikator) sehingga belum terlihat pengembangan dan target tingkat kinerja. 
3. Pembuatan model tata kelola IT untuk proses akademik menggunakan Cobit 4.1, Nur Aulia, Sri Hndayaningsih, program studi informatika Universitas Ahmad Dahlan, jurnal sarjana teknik informatika volume 1 nomor 1 Juni 2013, e-ISSN : 2338-5197;

Review : Adanya teori dan model analisis yang digunakan secara tepat, informasi yang didapat dari penelitian kurang lengkap dan detil, hal ini dilihat dari kesimpulan.

4. Audit sistem informasi menggunakan framework Cobit 4.1. pada e-learning UNISNU Jepara, Noor Azizah, Jurnal SIMETRIS, Vol 8 No 1 April 2017 ISSN: 2252-4983; Review : Pada kesimpulan belum menginformasikan fakta yang baru hanya bersifat normatif saja, dan belum terdapat saran-saran dalam penggunaan hasil dari pemetaan.

5. Audit keamanan sistem informasi pada kantor pemerintahan kota Yogyakarta menggunakan Cobit 5.1, Dewi Ciptaningrum, Eko Nugroho, Dani Adhipa, seminar nasional teknologi informasi dan komunikasi, 2015, (SENTIKA 2015) Yogyakarta 2015 ISSN : 2089-9815; Review : belum adanya dokumentasi kebijakan SOP untuk proses keamanan sistem informasi yang mengacu pada kerangka kerja Cobit 5 untuk keamanan informasi

\subsection{COBIT (Control Objectives for Information and Related Technology)}

COBIT dapat diartikan sebagai tujuan pengendalian untuk informasi dan teknologi terkait dan merupakan standar terbuka untuk pengendalian terhadap teknologi informasi yang dikembangkan dan dipromosikan oleh Institut IT Governance.[14]

COBIT pertama sekali diperkenalkan pada tahun 1996 adalah merupakan alat (tool) yang disiapkan untuk mengatur teknologi informasi (IT Governance tool).

COBIT telah dikembangkan sebagai sebuah aplikasi umum dan telah diterima menjadi standar yang baik bagi praktek pengendalian dan keamanan TI yang menyediakan sebuah kerangka kerja bagi pengelola, user, audit sistem informasi, dan pelaksana pengendalian dan keamanan.

COBIT, di terbitkan oleh Institut IT Governance. Pedoman COBIT memungkinkan perusahaan untuk mengimplementasikan pengaturan TI secara efektif dan pada dasarnya dapat diterapkan di seluruh organisasi. Khususnya, komponen pedoman manajemen COBIT yang berisi sebuah respon kerangka kerja untuk kebutuhan manajemen bagi pengukuran dan pengendalian TI dengan menyediakan alat-alat untuk menilai dan mengukur kemampuan TI perusahaan untuk 34 proses TI COBIT. Alat-alat tersebut yaitu :

1. Elemen pengukuran kinerja (pengukuran hasil dan kinerja yang mengarahkan bagi seluruh proses $\mathrm{TI}$ )

2. Daftar faktor kritis kesuksesan (CSF) yang disediakan secara ringkas, praktek terbaik non teknis dari tiap proses TI

3. Model maturity untuk membantu dalam benchmarking dan pengambilan keputusan bagi peningkatan kemampuan

\subsection{Kebutuhan Pengendalian Teknologi Informasi}

Agar organisasi meraih kesuksesan, maka perlu memperhatikan dan memahami mengenai resiko dan keterbatasan TI disemua level organisasi agar mencapai arahan yang efektif dan pengendalian yang memadai.

Manajemen harus memutuskan investasi yang memadai bagi pengendalian (control) dan keamanan (security) TI dan menyeimbangkan resiko dan investasi pengendalian yang tidak 
terprediksi dalam lingkungan TI. Oleh karena itu, kebutuhan terhadap manajemen kerangka kerja (framework) yang jelas, secara umum diterima sebagai praktek-praktek pengendalian dan keamanan TI untuk benchmark terhadap perencanaan dan kondisi TI yang ada.

Terdapat kebutuhan yang meningkat dari user atas layanan TI untuk penjaminan, akreditasi dan audit atas layanan TI, baik yang disediakan oleh pihak ketiga maupun yang disediakan oleh pihak internal.

Untuk mencapai tujuan organisasi secara memuaskan, informasi harus memenuhi beberapa kriteria. COBIT telah menetapkan kriteria tersebut dengan merujuk pada kebutuhan informasi di organisasi atau perusahaan. COBIT mengkombinasikan beberapa prinsip penyusunan informasi berdasarkan model-model yang sudah ada, dan merumuskannya kedalam tiga kategori utama, yaitu : kualitas (quality), tanggung jawab fidusier (fiduciary responsibility) dan keamanan (security).

Berdasarkan tiga persyaratan di atas, muncul tujuh kategori yang saling terkait satu sama lain, dan dijadikan sebagai kriteria untuk mengevaluasi sumberdaya teknologi informasi yang dapat memenuhi kebutuhan organisasi atau perusahaan akan suatu informasi.

Kriteria dimaksud adalah :[15]

(a) Efektivitas (Effectiveness), menguraikan informasi yang relevan dan berhubungan dengan proses bisnis yang disampaikan tepat pada waktunya dengan cara yang benar, konsisten dan tepat digunakan.

(b) Efisiensi (Efficiency), menyangkut ketentuan informasi melalui penggunaan sumberdaya yang optimal (lebih produktif dan ekonomis).

(c) Kerahasiaan (Confidentiality), menyangkut perlindungan informasi yang sensitif dari akses yang tidak sah.

(d) Integritas (Integrity), berkaitan dengan keakuratan dan kelengkapan informasi juga keabsahannya yang sesuai dengan harapan (expectation) dan nilai bisnis.

(e) Ketersediaan (Availability), berkaitan dengan informasi yang tersedia yang diperlukan oleh proses bisnis saat ini dan yang akan datang, juga menyangkut penjagaan sumberdaya yang perlu dan kemampuan yang terkait.

(f) Pemenuhan (Compliance), menguraikan pemenuhan hukum, peraturan dan persetujuan yang bersifat kontrak dimana proses bisnisnya merupakan subyek, yakni kriteria bisnis yang ditentukan dari luar.

(g) Keterandalan informasi (Reliability of Information), berkaitan dengan ketentuan informasi yang memadai bagi manajemen untuk menjalankan dan melaksanakan keseluruhan finansialnya dan pemenuhan laporan tanggung jawab.

\subsection{Pedoman Manajemen COBIT}

Institut IT Governance telah melakukan riset utama bekerja sama dengan kalangan akademisi, analis, dan para ahli dunia industri. Riset tersebut menghasilkan definisi pedoman manajemen untuk COBIT, yang terdiri dari model maturity, CSF, KGI, dan KPI, yang kemudian menyediakan manajemen dengan alat untuk menilai dan mengukur lingkungan TI organisasi terhadap 34 proses TI yang diidentifikasikan COBIT.

Terdapat perubahan besar dalam TI dan jaringan yang menekankan informasi elektronik dan sistem TI untuk mendukung proses bisnis kritis. Selanjutnya, bisnis yang sukses perlu pengaturan yang lebih baik dalam menghadapi teknologi yang komplek. Dengan meningkatnya pengungkapan kesalahan sistem informasi dan penyalahgunaan (fraud) elektronik, maka lingkungan organisasi memerlukan pengendalian yang teliti terhadap informasi. Saat ini 
manajemen TI terkait resiko tersebut dipahami sebagai bagian inti dari pengaturan perusahaan.[15]

Pengaturan TI yang merupakan bagian dari pengaturan perusahaan, menjadi lebih dirasakan peranannya dalam mencapai tujuan organisasi dengan menambah nilai melalui penyeimbangan resiko terhadap nilai kembali atas TI dan prosesnya.

Pengaturan TI merupakan pelengkap suksesnya pengaturan perusahaan melalui peningkatan yang efisien dan efektif sehubungan dengan proses perusahaan. Pengaturan TI menyediakan stuktur yang berhubungan dengan proses TI, sumberdaya TI, dan informasi untuk strategi dan tujuan perusahaan. Lebih lanjut, pengaturan TI mengintegrasikan dan melembagakan praktek yang berhubungan dengan PO, AI, DS, dan ME kinerja TI untuk menjamin bahwa informasi perusahaan dan teknologi terkait mendukung tujuan bisnisnya. Selain itu pengaturan TI memungkinkan perusahaan mengambil keuntungan dari informasi tersebut.

Model maturity untuk pengendalian terhadap proses TI terdiri dari pengembangan suatu metode penyusunan agar suatu organisasi dapat menilai tingkatan posisinya dari non-existent ke optimised (dari 0 sampai 5).

Pendekatan ini diambil dari Maturity Model Software Engineering Institute yang diterapkan untuk kematangan kemampuan pengembangan software. Terhadap tingkat ini, dikembangkan untuk setiap 34 proses TI COBIT, manajemen dapat menggambarkan :

a) status organisasi saat ini - dimana organisasi saat ini

b) status terbaik industri saat ini (dikelasnya) - sebagai perbandingan

c) status standar internasional saat ini - sebagai perbandingan

d) strategi organisasi untuk perbaikan atau peningkatan - ke arah mana keinginan organisasi

Critical Success Factors (CSF) menetapkan masalah terpenting atau tindakan untuk manajemen mencapai pengendalian proses TI. CSF harus mengatur orientasi pedoman implementasi dan mengidentifikasikan hal terpenting yang dilakukan secara strategis, teknis, organisasional atau prosedur.

\subsection{Metoda AHP (Analytical Hierarchy Process) Pengertian AHP ( Analitycal Hierarchy Process )}

AHP merupakan suatu model pendukung keputusan yang dikembangkan oleh Thomas L. Saaty. Model pendukung keputusan ini akan menguraikan masalah multi faktor atau multi kriteria yang kompleks menjadi suatu hirarki. Hirarki didefinisikan sebagai suatu representasi dari sebuah permasalahan yang kompleks dalam suatu struktur multi level dimana level pertama adalah tujuan, yang diikuti level faktor, kriteria, sub kriteria, dan seterusnya ke bawah hingga level terakhir dari alternatif. Dengan hirarki, suatu masalah yang kompleks dapat diuraikan ke dalam kelompok-kelompoknya yang kemudian diatur menjadi suatu bentuk hirarki sehingga permasalahan akan tampak lebih terstruktur dan sistematis.[20]

AHP sering digunakan sebagai metode pemecahan masalah dibanding dengan metode yang lain karena alasan-alasan sebagai berikut:

1. Struktur yang berhirarki, sebagai konsekuesi dari kriteria yang dipilih, sampai pada subkriteria yang paling dalam.

2. Memperhitungkan validitas sampai dengan batas toleransi inkonsistensi berbagai 
kriteria dan alternatif yang dipilih oleh pengambil keputusan.

3. Memperhitungkan daya tahan output analisis sensitivitas pengambilan keputusan.

\section{HASIL DAN PEMBAHASAN}

Dari hasil pengolahan data dengan menggunakan metoda AHP maka dibuat grafik skala prioritas hasil perhitungan eigen value untuk domain DS dan ME pada responden pertama dan kedua.

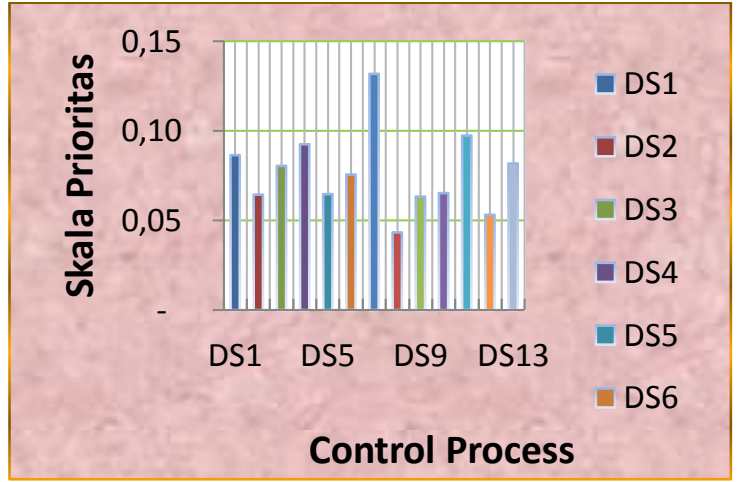

Grafik 1. Skala prioritas domain DS pada responden pertama

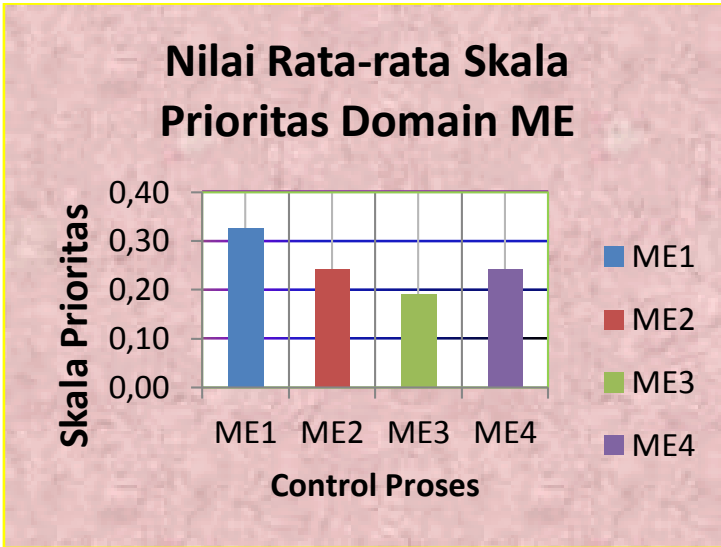

Grafik 2. Skala prioritas domain ME pada responden pertama 


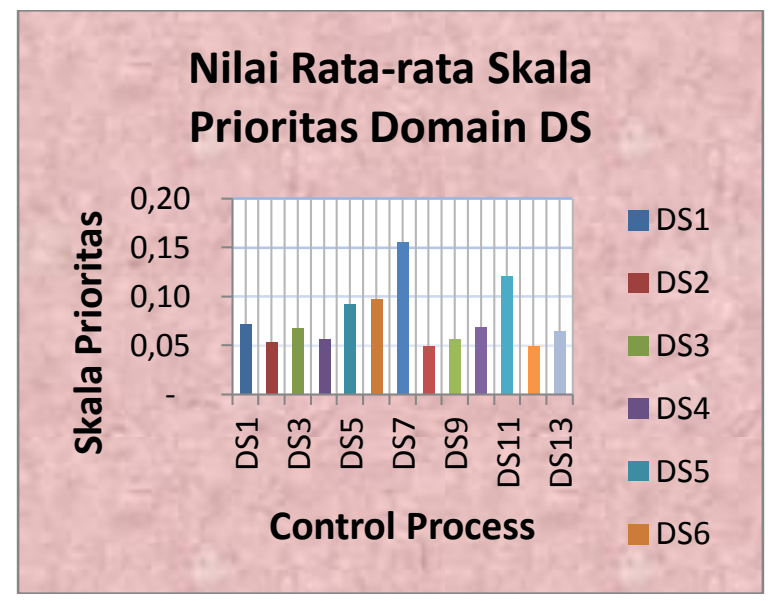

Grafik 3. Skala prioritas domain DS pada responden kedua

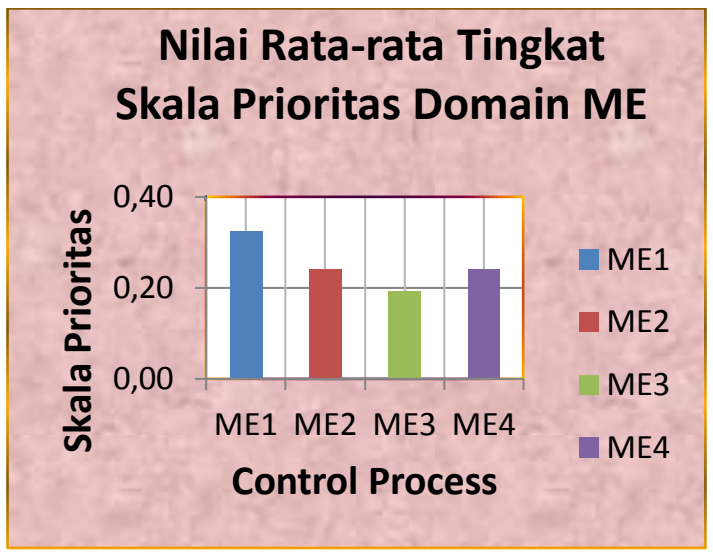

Grafik 4. Skala prioritas domain ME pada responden kedua

\subsection{Usulan Tata Kelola It (It Governance)}

Tata kelola IT Governance p a d a institusi diadopsi dari model COBIT. COBIT dapat diartikan sebagai tujuan pengendalian untuk informasi dan teknologi terkait dan merupakan standar terbuka untuk pengendalian terhadap teknologi informasi yang dikembangkan dan dipromosikan oleh institut IT Governance. Pedoman COBIT memungkinkan sebuah institusi mengimplementasikan pengelolaan TI secara efektif. Pada dasarnya COBIT dapat diterapkan di seluruh organisasi, oleh karena itu tata pengelolaan TI COBIT harus disesuaikan dengan lingkungan Institusi, dengan mempertimbangkan proses bisnis dan tanggung jawab proses teknologi informasi terhadap aktivitas institusi. Adanya integrasi antara pengelolaan IT institusi dan optimalisasi institusi melalui domain pada COBIT yaitu Delivery and Support (DS), Monitoring and Evaluation (ME) dan menjamin efisiensi dan efektivitas perbaikan pengukuran dalam kaitan dengan proses institusi. 


\subsection{Tahapan Tata Kelola Model IT Governance}

Tahapan rancangan model IT Governance adalah :

1. Menetapkan domain

Dalam penelitian ini domain yang dipilih yaitu domain DS dan ME.

2. Menetapkan control process

Pada tahap ini telah ditetapkan control process dengan nilai prioritas tertinggi pertama dan nilai prioritas tertinggi yang kedua dari domain DS, kemudian menetapkan control process dengan nilai prioritas tertinggi pada domain ME. Dalam menentukan nilai prioritas tertinggi dipergunakan perhitungan dengan metoda Analytical Hierarchy Process (AHP).

3. Menetapkan CSF TI Institusi

Menetapkan CSF tiap-tiap proses pada domain sistem informasi institusi. CSF adalah merupakan faktor kritis kesuksesan yaitu merupakan kumpulan hal-hal yang harus ada atau aktifitas-aktifitas yang harus dilakukan untuk memastikan keberhasilan setiap proses untuk mencapai tujuannya.

4. Membuat kuesioner

Berdasarkan tujuan pengendalian yang telah ditetapkan, dibuat kuesioner sebagai bahan bagi pengumpulan fakta pada tiap-tiap proses.

5. Membuat tingkat model maturity

6. Memetakan posisi TI Institusi

7. Memberikan usulan IT Governance

Berdasarkan tahapan rancangan model IT Governance, maka ditentukan untuk domain dan control processnya.

\subsection{Domain Deliver and Support (DS)}

\section{Mendidik dan Melatih Pengguna}

Untuk mendidik dan melatih pengguna yang perlu dipertimbangkan adalah jenjang pendidikan pengguna, dukungan manajemen institusi, kemampuan teknis pengguna, , formalisasi pengembangan sistem informasi, adanya program-program pendidikan dan pelatihan pengguna. Dengan memperhatikan hal tersebut, diharapkan akan adanya kepuasan pengguna sistem informasi dan pembuat sistem.

\section{Critical Success Factors (CSF)}

1. Diperlukan perencanaan pelatihan yang terstruktur dan terdokumentasi serta teridentifikasi sesuai dengan kebutuhan organisasi, menetapkan standar kurikulum pelatihan secara tepat serta selalu monitoring dan evaluasi terhadap kegiatan tersebut.

2. Fungsi pelatihan dan pendidikan harus memiliki kemampuan untuk meningkatkan kualitas karyawan yang menguasai IT serta menjadikan pengembangan jalur karir karyawan.

3. Pihak manajemen selalu meninjau ulang dan mengupdate program dan proses-proses pelatihan secara berkala.

\section{Mengelola Data}

Langkah-langkah mengelola data adalah dengan melakukan pengumpulan data, penginputan pada sumber data, pemeliharaan data, pengendalian data dan menghasilkan informasi kepada pengguna. Dalam pemeliharaan data melibatkan langkah-langkah pengklasifikasian, pemindahan atau penggandaan, penyortiran, pengelompokkan, penghitungan, perbandingan, dan rangkuman. 


\section{Critical Success Factors (CSF)}

1. Terdapat standar operasional yang sifanya formal dalam hal back up, restore dan manajemen data.

2. Kualitas data terukur dan kepuasan user akan ketersediaan data dimonitor

3. Terdapat penjadwalan pelatihan yang rutin untuk seluruh proses pengelolaan data.

\section{Monitor and Evaluate}

Dalam domain keempat pada COBIT, berfokus kepada pemeriksaan intern, ekstern, dan jaminan kebebasan dari proses pemeriksaan yang dilakukan. Dan domain ini juga mengawasi dan mengevaluasi performa teknologi informasi dan kontrol internal.

\section{Monitor dan Evaluasi Kinerja TI}

Semua proses TI perlu dinilai secara teratur dan berkala bagaimana kualitas dan kesesuaiannya dengan kebutuhan kontrol, serta mengevaluasi kinerja TI untuk memberikan solusi pelayanan yang baik.

\section{Critical Success Factors (CSF)}

1. Adanya standarisasi operasional yang tinggi.

2. Diperlukan koordinasi langsung dengan proses-proses yang terkait, termasuk fungsi manajemen perubahan dan permasalahan

3. Rasionalisasi dan standarisasi perangkat manajemen sistem telah diterapkan.

4. Perubahan penjadwalan kerja dikendalikan secara ketat.

\section{Uji Validitas}

Validitas adalah ketepatan atau kecermatan suatu instrumen dalam mengukur apa yang ingin dukur. Dalam pengujian instrumen pengumpulan data, validitas bisa dibedakan menjadi validitas faktor dan validitas item. Validitas faktor diukur bila item yang disusun menggunakan lebih dari satu faktor (antara faktor satu dengan yang lain ada kesamaan). Pengukuran validitas faktor ini dengan cara mengkorelasikan antara skor faktor (penjumlahan item dalam satu faktor) dengan skor total faktor (total keseluruhan faktor), sedangkan pengukuran validitas item dengan cara mengkorelasikan antara skor item dengan skor total item.

Hasil uji validitas untuk control process DS-7 terdapat pada tabel berikut ini :

Tabel 1 Nilai korelasi untuk control process

DS7-Mendidik dan Melatih Pengguna

\begin{tabular}{|c|c|c|}
\hline $\begin{array}{c}\text { No. } \\
\text { Pertanyaan }\end{array}$ & $\begin{array}{c}\text { Koefisien } \\
\text { Korelasi }\end{array}$ & Keterangan \\
\hline 1 & 0.55 & Valid \\
\hline 2 & 0.55 & Valid \\
\hline 3 & 0.62 & Valid \\
\hline 4 & 0.47 & Valid \\
\hline 5 & 0.76 & Valid \\
\hline 6 & 0.64 & Valid \\
\hline 7 & 0.59 & Valid \\
\hline 8 & 0.79 & Valid \\
\hline 9 & 0.63 & Valid \\
\hline 10 & 0.75 & Valid \\
\hline
\end{tabular}


Tabel 2 Nilai korelasi control process DS11-Mengelola data

\begin{tabular}{|c|c|c|c|}
\hline $\begin{array}{c}\text { No. } \\
\text { Pertanyaan }\end{array}$ & $\begin{array}{c}\text { Koefisien } \\
\text { Korelasi }\end{array}$ & Keterangan & \\
\hline 1 & 0.75 & Valid & \\
\hline 2 & 0.81 & Valid & \\
\hline 3 & 0.55 & Valid & \\
\hline 4 & 0.68 & Valid & \\
\hline 5 & 0.72 & Valid & \\
\hline 6 & 0.46 & Valid & \\
\hline 7 & 0.62 & Valid & \\
\hline 8 & 0.66 & Valid & \\
\hline 9 & 0.77 & Valid & \\
\hline 10 & 0.65 & Valid & \\
\hline 11 & 0.64 & Valid & \\
\hline 12 & 0.64 & Valid & \\
\hline
\end{tabular}

Tabel 3 Nilai korelasi control process

ME1-Monitor dan evaluasi kinerja TI

\begin{tabular}{|c|c|c|}
\hline $\begin{array}{l}\text { No. } \\
\text { Pertanyaan }\end{array}$ & $\begin{array}{l}\text { Koefisien } \\
\text { Korelasi }\end{array}$ & Keterangan \\
\hline 1 & 0.76 & Valid \\
\hline 2 & 0.88 & Valid \\
\hline 3 & 0.78 & Valid \\
\hline 4 & 0.87 & Valid \\
\hline 5 & 0.83 & Valid \\
\hline 6 & 0.88 & Valid \\
\hline 7 & 0.82 & Valid \\
\hline 8 & 0.85 & Valid \\
\hline
\end{tabular}

\section{Uji Realibilitas}

Uji reliabilitas dihitung menggunakan software aplikasi Statistic Package for Social Student (SPSS) yang hasilnya untuk masing-masing control process yaitu pada tabel 5.8. berikut ini :

Tabel 4 Nilai Reliabel pada Control Process: DS7, DS11, ME1

\begin{tabular}{|l|c|c|c|}
\hline Nama Variabel & Cronbach's Alpha & Nilai & Keterangan \\
\hline $\begin{array}{l}\text { Mendidik dan melatih user } \\
\text { (DS-7) }\end{array}$ & 0.85 & 0.50 & Reliabel \\
\hline Mengelola Data (DS-11) & 0.89 & 0.50 & Reliabel \\
\hline $\begin{array}{l}\text { Monitor dan Evaluasi (ME- } \\
\text { 1) }\end{array}$ & 0.90 & 0.50 & Reliabel \\
\hline
\end{tabular}

Dari hasil tabel didapatkan nilai cronbach's Alphanya antara 0,70-0,90 artinya kuesioner yang digunakan dalam penelitian ini dalam mengumpulkan data reliabelnya tinggi (dapat dipercaya).

Dari hasil uji validitas dan uji reabilitas didapatkan bahwa hasil penelitian ini dalam mengumpulkan data dari pihak responden dapat dipertanggungjawabkan. 


\section{Hasil Kuesioner}

Berikut ini hasil perhitungan kuesioner dan tingkat model maturity ada pada tabel 5 di bawah ini :

Tabel 5 Hasil Kuesioner

\begin{tabular}{|c|c|c|c|c|}
\hline Proses & $\begin{array}{l}\text { Jumlah } \\
\text { jawaban }\end{array}$ & $\begin{array}{l}\text { Jumlah } \\
\text { pertanyaan }\end{array}$ & Indeks & $\begin{array}{c}\text { Tingkat model } \\
\text { maturity }\end{array}$ \\
\hline \multicolumn{5}{|l|}{ Deliver and Support } \\
\hline $\begin{array}{c}\text { DS7 - Mendidik dan } \\
\text { melatih } \\
\text { pengguna }\end{array}$ & 36 & 10 & 3.60 & 4 \\
\hline DS11 - Mengelola & 47 & 12 & 3.92 & 4 \\
\hline \multicolumn{5}{|l|}{\begin{tabular}{|l} 
Monitoring and \\
\end{tabular}} \\
\hline $\begin{array}{c}\text { ME1-Memonitor dan } \\
\text { mengevaluasi } \\
\text { kinerja TI }\end{array}$ & 26 & 8 & 3.25 & 3 \\
\hline
\end{tabular}

\section{Posisi SI Institusi}

\section{a. DS7-Mendidik dan melatih pengguna}

Berdasarkan model maturity, proses ini berada pada tingkat 4-Diatur, artinya :

1. Program pendidikan dan pelatihan pengguna (user) disesuaikan dengan jenjang pendidikan, kemampuan teknis dalam penggunaan dan pengembangan sistem informasi.

2. Institusi harus memberikan perhatian khusus terhadap pendidikan dan pelatihan yang akan berdampak peningkatan karir dan kinerja SDM.

3. Adanya dukungan infrastruktur, anggaran yang dibutuhkan dalam menyelenggarakan pendidikan dan pelatihan.

\section{b. DS11 - Mengelola data}

Berdasarkan model maturity, proses ini berada pada tingkat 4-Diatur, artinya :

1. Melakukan backup data melalui mekanisme redudansi dan duplikasi.

2. Adanya prosedur pengelolaan data berdasarkan standar tertentu.

3. Adanya kesesuaian mekanisme penjagaan integritas data yang ditetapkan.

4. Melakukan pengawasan integritas secara otomatis terhadap sejumlah komponen infrastruktur secara kritis.

\section{c. ME1 - Monitor dan evaluasi kinerja IT}

Berdasarkan model maturity, proses ini berada pada tingkat 3-Ditetapkan, artinya:

1. Pada proses monitoring yang harus diperhatikan tidak hanya pada saat input, pemrosesan dan output tetapi juga yang perlu diperhatikan pada saat pra input dan pasca output.

2. Monitoring seharusnya dilakukan secara aktif untuk semua kegiatan yang berhubungan dengan proses TI, yang disesuaikan dengan kebutuhan untuk mendukung kinerja TI. 
3. Adanya metode dan teknik yang standar untuk monitoring dan mengevaluasi kinerja TI yang terintegrasi dengan seluruh proses TI yang ada.

\section{Usulan Tata Kelola IT (IT Governance)}

Usulan untuk tata kelola IT (IT Governance untuk control process DS7- Mendidik dan melatih pengguna, DS11- Mengelola Data, dan ME1- Monitor dan evaluasi kinerja TI, dapat dilihat pada tabel di bawah ini :

\section{Tabel 6 Usulan IT Governance}

\begin{tabular}{|c|c|c|}
\hline No & Proses & Usulan IT Governance \\
\hline 1. & $\begin{array}{l}\text { Mendidik dan } \\
\text { melatih } \\
\text { pengguna } \\
\text { (user) }\end{array}$ & $\begin{array}{l}\text { Pendidikan dan pelatihan diselenggarakan secara berkala } \\
\text { (minimal sekali dalam setahun) dengan memperhatikan } \\
\text { kebutuhan bisnis saat ini dan masa mendatang serta kemampuan } \\
\text { dan kebutuhan saat ini }\end{array}$ \\
\hline 2. & $\begin{array}{l}\text { Mengelola } \\
\text { Data }\end{array}$ & $\begin{array}{l}\text { - Mengatur dan mengimplementasikan otorisasi user dalam } \\
\text { mengakses data yang ada. } \\
\text { - Melakukan backup data yang teratur sehingga dapat } \\
\text { mengamankan data yang ada jika terjadi sesuatu yang dapat } \\
\text { merusak data }\end{array}$ \\
\hline 3. & $\begin{array}{l}\text { Monitor dan } \\
\text { evaluasi } \\
\text { kinerja TI }\end{array}$ & $\begin{array}{l}\text { Ditetapkannya mekanisme pengawasan dan penilaian kinerja TI } \\
\text { pada sistem informasi akademik di STMIK } \\
\text { "AMIKBANDUNG", serta menggunakan standar tertentu }\end{array}$ \\
\hline
\end{tabular}

Dari hasil pengujian dan rekomendasi permasalahan yang ada di STMIK "AMIKBANDUNG" dapat diselesaikan dengan menggunakan pendekatan dan metode yang terstruktur, dimana proses pemetaan ada di level maturity ke-empat, artinya proses pelaksanaan teknologi informasi di istitusi sudah mengikuti pola yang teratur namun harus selalu dimonitoring secara aktif untuk meningkatkan pelayanan akademik.

\section{KESIMPULAN DAN SARAN}

\subsection{Kesimpulan}

Dari pembahasan terhadap rancangan model IT Governance dapat ditarik kesimpulan :

1. Hasil pemetaan proses TI di peroleh gambaran, bahwa posisi institusi untuk tiap proses rata - rata berada ditingkat (level) maturity ke-empat yaitu diatur, artinya dalam pelaksanaan TI di institusi selama ini sudah mengikuti pola yang teratur.

2. Untuk meningkatkan karir dan kinerja sumber daya manusia, institusi harus memberikan perhatian khusus terhadap pendidikan dan pelatihan.

3. Pihak manajemen selalu meninjau ulang dan mengupdate program dan proses-proses pelatihan secara berkala.

4. Pengawasan (system monitoring) seharusnya dilakukan secara aktif untuk semua kegiatan yang berhubungan dengan proses TI, yang disesuaikan dengan kebutuhan untuk mendukung kinerja TI serta mengutamakan system pelayanan akademik.

\subsection{Saran}

Sebagai saran dari hasil pembahasan tesis dapat dikemukakan sebagai berikut :

1. Manajemen atau pihak institusi perlu memberikan pelatihan dan pendidikan secara berkala 
(minimal sekali dalam setahun) dibidang IT bagi staf/karyawan, dosen, yang berkompeten di bidang IT.

2. Sebaiknya untuk penelitian selanjutnya tidak hanya membahas domain deliver and support, dan monitoring and evaluation saja, tetapi dilakukan secara keseluruhan domain pada kerangka kerja COBIT, yaitu ditambah dengan domain plan and organise dan Acquire and Implement, sehingga dapat dilakukan evaluasi IT Governance secara keseluruhan untuk sistem informasi akademik di STMIK "AMIKBANDUNG", dan juga diharapkan tidak hanya pada sistem informasi akademik saja tetapi sistem yang lain pun perlu dilakukan evaluasi.

5. Diharapkan untuk penelitian selanjutnya membuat suatu perangkat lunak (software) pendukung yang dapat digunakan untuk sebaran kuesioner secara online sehingga tidak memerlukan waktu yang lama dalam pengumpulan data.

\section{DAFTAR PUSTAKA}

[1] Ade Putri Marina dan Surendro Kridanto., "Perancangan Model Kapabilitas Proses Pengelolaan Sumber Daya Teknologi Informasi” Jurnal Sarjana ITB Bidang Teknik Elektro Volume 1, Number 2, Juli 2012

[2] Chintamia Bunga Sari Dewi., Analisis pengelolaan teknologi informasi berbasis framework cobit 4.1., jurnal ilmiah informatika

[3] Agus Prasetyo Utomo dan Novita Mariana., "Analisis Tata Kelola Teknologi Informasi (IT Governance) pada Bidang Akademik dengan COBIT Framework Studi Kasus pada Universitas STIKUBANK Semarang" Jurnal Teknologi Informasi DINAMIK Volume 16, Number 2, juli 2012:139-149

[4] Budiono Gatut.,"Audit Kinerja Sistem Informasi Manajemen Pemeliharaan Unit Pembangkit Listrik Berbasis COBIT Domain" Jurnal EECCIS Volume IV, Number 1, Juni 2010

[5] Desy Iba Ricoida., "Perancangan Tata Kelola TI untuk Peningkatan Layanan Sistem Informasi Akademik Studi Kasus STMIK MDP” Jurnal Ilmiah Volume 4 Number 2, Juni 2008

[6] Diana Trivena Yulianti dan Michel Canggih Patria.,"Audit Sistem Informasi Sumber Daya Manusia pada PT X Menggunakan COBIT Framework 4.1”, Jurnal Sistem Informasi, Volume 6, Number 1, Maret 2011; 15-33

[7] Dewi Ciptaningrum, Eko Nugroho, Dani Adhipa., Audit keamanan sistem informasi pada kantor pemerintahan kota Yogyakarta menggunakan Cobit 5.1., seminar nasional teknologi informasi dan komunikasi 2015, (SENTIKA 2015) Yogyakarta 2015 ISSN : 2089-9815.

[8] Effendi, Diana., “Perancangan IT Governance Pada Layanan Akademik di UNIKOM (Universitas Komputer Indonesia ) menggunakan COBIT (Control Objective for Information and Related Technology) Versi 4.0", Tesis S2 ITB 2008

[9] Fitriana Devi, Yudho Giri Sucahyo.," Audit Sistem Informasi Teknologi Informasi dengan kerangka Kerja COBIT untuk Evaluasi Manajemen Teknologi Informasi di Universitas XYZ”, Jurnal Sistem Informasi MTI-UI, Volume 4, Number 1, ISBN 1412-8896, 2011

[10] Grembergen, Win Van., "Strategies for Information Technology Governance”, Idea Group Publishing, 2004 
[11] Gultom Manorang.,"Audit Tata Kelola Informasi pada PTPN 13 Pontianak Menggunakan Framework COBIT" Jurnal Socio Scienta Kopertis Wilayah XI Kalimantan, Volume 4 Number 1, Februari 2012.

[12] Hamzah Ardi.," Tatalaksana Teknologi Informasi Metode COBIT" Seminar Nasional Aplikasi Teknologi Informasi 2006 (SNATI 2006) ISSN:1907-5022

[13] Handoko, Hani., “Manajemen Personalia dan Sumberdaya Manusia”,Yogyakarta, BPFE, 1996

[14] ISACA.,"COBIT Student Book”, IT Governance Institute, 2004

[15] ISACA., "Integrating COBIT into the IT Audit Process (Planning, Scope Development, Practises"), IT Governance Institute, 2006

[16] IT Governance Institute., " COBIT 4.0 Control Objectives, Management Guidelines, Maturity Models”, IT Governance Institute, 2005

[17] IT Governance Institute., "IT Governance Implementation Guide 2 $2^{\text {nd, }}, 2007$

[18] Hermawan Iwan.,"Model COBIT Sebagai Kerangka Kerja Tata Kelola Arsitektur Sistem dan Teknologi Informasi pada Politeknik Negeri Semarang" Jurnal Ilmiah USM, TransForMatika ISSN 1693-3656 Volume 9, Number 1, Hal 16-28.

[19] Jusuf Heni., "IT Governance pada Layanan Akademik on line di Universitas Nasional menggunakan COBIT versi 4.0", Seminar Nasional Aplikasi Teknologi Informasi 2009 (SNATI 2009) ISSN :1907-5022

[20] Nurhayani.," Tata Kelola Teknologi Informasi pada Layanan Akademik AMIK SIGMA Palembang Menggunakan COBIT" Jurnal Ilmiah Informatika Global ISSN 2302-500x Volume 1 Number 1, Juli 2010.

[21] Nur Aulia, Sri Handayaningsih., Pembuatan model tata kelola IT untuk proses akadmik menggunakan Cobit 4.1., program studi informatika Universitas Ahmad Dahlan, jurnal sarjana teknik informatika volume 1 nomor 1 Juni 2013, E-ISSN : 2338-5197.

[22] Noor Azizah., Audit sistem informasi menggunakan framework Cobit 4.1. pada e-learning UNISNU Jepara., jurnal SIMETRIS, Vol. 8 No 1 April 2017 ISSN : 2252-4983.

[23] Purwanto.,"Evaluasi Tata Kelola Teknologi Informasi Menggunakan Kerangka Kerja COBIT dalam Mendukung Layanan Sistem Informasi Akademik Studi Kasus : University Budi Luhur" Jurnal TELEMATIKA Mkom, Volume 2 Number 1 Maret 2010 ISSN 2085$725 \mathrm{x}$

[24] Saaty, L Thomas and Luis., "Decision Making in Economic, Political, Social and Technological Environments with the Analytic Hierarchy Process", University of Pittsburgh, 1994

[25] Sekaran, Uma. (2003), Research Methods For Business $4^{\text {th }}$, John Wiley and Sons Inc. 